\title{
ZASTOSOWANIE METODY WIELOKRYTERIALNEJ DO ANALIZY DIAGNOSTYCZNEJ PACJENTA Z CHOROBA ZWYRODNIENIOWĄ STAWU BIODROWEGO
}

\author{
LUIZA FABISIAK ${ }^{1}$, KARINA SZCZYPIÓR-PIASECKA ${ }^{2}$, \\ RYSZARD BUDZIŃSKI ${ }^{3}$, PAWEŁ ZIĘTEK ${ }^{4}$ \\ ${ }^{1}$ Zachodniopomorski Uniwersytet Technologiczny w Szczecinie \\ Wydział Informatyki, Katedra Inżynierii Oprogramowania \\ e-mail:1fabisiak@wi.zut.edu.pl \\ ${ }^{2}$ Pomorski Uniwersytet Medyczny \\ Katedra i Klinika Ortopedii, Traumatologii i Onkologii Narządu Ruchu \\ e-mail: karinaszczypior@interia.pl \\ ${ }^{3}$ Uniwersytet Szczeciński \\ Wydział Nauk Ekonomicznych i Zarządzania \\ Instytut Informatyki w Zarządzaniu \\ e-mail: ryszard.budzinski@wneiz.pl \\ ${ }^{4}$ Pomorski Uniwersytet Medyczny \\ Katedra i Klinika Ortopedii, Traumatologii i Onkologii Narządu Ruchu \\ e-mail: paulz@wp.pl
}

SŁOWA KLUCZOWE

STRESZCZENIE
MCDM, Electre Tri, AHP, choroba zwyrodnieniowa stawu biodrowego

Artykuł przedstawia wielokryterialną procedurę postępowania przy kwalifikacji pacjentów do zabiegu wymiany stawu biodrowego w procesie leczenia. Zastosowano metodę Electre Tri w hybrydowym systemie DSS 3.0. Artykuł składa się z opisu kompetencji ekspertów, drzewa decyzyjnego oraz modelowania rankingów i klasyfikacji podjętego problemu. Przykładem badawczym są pacjenci z różnym zaawansowaniem choroby zwyrodnieniowej, których stan określono w trakcie leczenia szpitalnego.

\section{Wprowadzenie}

Zaawansowane zmiany zwyrodnieniowe powodują zaburzenia w biomechanice, wystąpienie innych dysfunkcji, niesprawność i izolację społeczną. Mnogość uwarunkowań o różnym nasileniu stanu pacjenta powoduje problem z ustaleniem optymalnego momentu leczenia operacyjnego pacjentów z chorobą zwyrodnieniową stawu biodrowego. Problem klasyfikacji pacjentów do operacji jest złożony. Opublikowane badania ukazują różnorodność parametrów, wariantów, 
klasyfikacji pacjentów z chorobą zwyrodnieniową stawu biodrowego. Srokowski i współpracownicy w swojej pracy oceniali jakość chodu oraz stan funkcjonalny pacjentów zakwalifikowanych do zabiegu endoprotezoplastyki (Srokowski, Bułatowicz i in., 2010). Kolejnym kryterium jest zależność między obniżeniem siły mięśniowej a występowaniem choroby zwyrodnieniowej stawu biodrowego oraz najbardziej powtarzalne i miarodajne testy funkcji, takie jak marsz oraz chód po schodach (Arokoski, Haara i in., 2004; Arokoski, 2002; Suetta, 2007). Zauważa się przy tym ubogość propozycji oceniających wszystkie najważniejsze parametry z zakresu biomechaniki w jednym systemie i w tym kontekście klasyfikację chorego pacjenta do zabiegu operacyjnego. Jest to zasadniczy problem medyczny wymagający odpowiedniego rozwiązania Problem drugi to dobór adekwatnej metody (systemu) wspomagania decyzji w tym zakresie.

Współcześnie prowadzący analizy dysponują dużą ilością wypracowanych metod związanych $\mathrm{z}$ interpretacją odwzorowanych zjawisk. Powstaje problem użyteczności tych metod dla konkretnych problemów decyzyjnych. Celem artykułu jest wypracowanie (i zweryfikowanie) procedury badawczej dla oceny choroby zwyrodnieniowej stawu biodrowego. Zweryfikowanie odpowiedniej metody wielokryterialnej pozwoli na precyzyjne ustalenie kwalifikacji pacjenta do zabiegu

\section{Uwarunkowania formalnej oceny wielokryterialnego problemu decyzyjnego u badanych pacjentów}

Operacja niesie za sobą poprawę stanu funkcjonalnego, ale również ryzyko powikłań i innych zagrożeń. Choroba zwyrodnieniowa stawu biodrowego jest chorobą przewlekłą, w której nie da się cofnąć zaistniałych zmian. Odpowiednio dobrany program fizjoterapii jest w stanie spowolnić postęp choroby. Analizie zostały poddane dane badanych pacjentów obejmujące stan ich zdrowia. Mimo istnienia różnorodnych metod wspomagania decyzji, dylematem pozostaje nadal dobór odpowiedniego zestawu narzędzi indywidualnie na potrzeby badanego problemu. $\mathrm{W}$ praktyce istnieje wiele metod prezentujących różne podejścia do rozwiązań problemów decyzyjnych. Techniki agregacji wielu kryteriów stosowane w metodach MCDA/MCDM (Wielokryterialnej Analizy Decyzji / Wielokryterialnego Podejmowania Decyzji) zgrupowane są w trzy następujące modele technik agregacji:

- forma relacyjna, oparta na relacji przewyższania;

- forma funkcyjna, oparta na funkcji użyteczności;

- forma symboliczna, oparta na regułach decyzyjnych (Lexer, Vakic, 2007).

W metodologii badawczej do rozwiązania celu pracy zaproponowano metodę Electre Tri, która stosowana jest do zagadnienia klasyfikacyjnego. W metodzie tej relacja przewyższania używana jest do szacowania stopnia przewyższania wariantów decyzyjnych $a$ (obiektów) nad profile $b$, które separują od siebie klasy (Dumpos, Zopounidis, 2002). Metoda ta zajmuje się zagadnieniem sortowania i wykorzystuje pseudokryteria, które wyznaczają współczynniki zgodności i wiarygodności oraz wskaźniki niezgodności. Podczas wyznaczania tych wartości zachodzą tylko niewielkie różnice dotyczące przynależności progów równoważności, preferencji 
i weta do poszczególnych przedziałów. Mianowicie współczynniki zgodności i wiarygodności opisane są wzorami (1) i (2):

$$
c\left(a_{2}, b_{j}\right)=\frac{\sum_{i=1}^{n} w_{i} \cdot v_{2}\left(a_{i}, b_{j}\right)}{\sum_{k=1}^{n} w_{j}}
$$

gdzie wskaźniki zgodności $\varphi_{k}$ mogą przyjąć wartości:

- $\varphi_{k}\left(a_{i}, b_{j}\right)=1$, gdy $f_{k}\left(b_{j}\right)-f_{k}\left(a_{i}\right)<q_{k}$

- $\varphi_{k}\left(a_{i}, b_{j}\right)=0$, gdy $f_{k}\left(b_{j}\right)-f_{k}\left(a_{i}\right) \geq p_{k}$

- $\varphi_{k}\left(a_{i}, b_{j}\right)=\frac{f_{k}\left(a_{i}\right)+\hat{o}_{k}-f_{k}\left(b_{j}\right)}{p_{k}-\hat{\vartheta}_{k}}, g d y q_{k}<f_{k}\left(b_{j}\right)-f_{k}\left(a_{i}\right) \leq p_{k}$

oraz:

$$
\sigma\left(a_{i}, b_{j}\right)=c\left(a_{i}, b_{j}\right) * \prod_{k \in D_{i}\left(a_{i}, b_{j}\right)}^{1-d_{i}\left(a_{a}, b_{j}\right)}
$$

gdzie wskaźniki niezgodności mogą przyjąć wartości:

- $d_{k}\left(a_{i}, b_{j}\right)=1, g d y f_{k}\left(b_{j}\right)-f_{k}\left(a_{i}\right) \geq v_{k}$

$-d_{k}\left(a_{i}, b_{j}\right)=0$, gdy $f_{k}\left(b_{j}\right)-f_{k}\left(a_{i}\right)<p_{k}$

$-d_{k}\left(a_{i}, b_{j}\right)=\frac{f_{i}\left(b_{j}\right)-f_{i}\left(a_{i}\right)-p_{2}}{v_{i}-b_{i}}$, gdy $p_{k} \leq f_{k}\left(a_{j}\right)-f_{k}\left(a_{i}\right)<v_{k}$

Nieprzypadkowo $\mathrm{w}$ powyższych wzorach użyto notacji zapisu wariantów jako $a_{i}$ i $b_{j}$. Zapis ten wynika z faktu, że w metodzie Electre Tri warianty decyzyjne $\left(a_{i}\right)$ porównywane są z profilami wariantów $\left(b_{j}\right)$. Profile są ,sztucznymi wariantami” ograniczającymi poszczególne klasy jakościowe. Są one definiowane przez decydenta w momencie ustalania wartości progów i wag kryteriów. Ważne jest, aby profile były określone poprawnie, tzn. aby profil zdefiniowany jako najlepszy istotnie był profilem optymalnym, itd. Poprawne zdefiniowanie profili pozwala poprawnie uszeregować klasy jakościowe. Na podstawie wyznaczonego współczynnika wiarygodności i zdefiniowanego przez decydenta poziomu cięcia $\lambda$ wyznaczane są relacje $\lambda$-preferencji między wariantami a profilami. Relacje wyznaczane są według następujących reguł:

$-a_{i} I b_{j} \Leftrightarrow\left(a_{i} S b_{j}\right) \wedge\left(b_{j} S a_{i}\right)$
$-a_{i}>b_{j} \Leftrightarrow\left(a_{i} S b_{j}\right) \wedge \sim\left(b_{j} S a_{i}\right)$
$-a_{i}<b_{j} \Leftrightarrow \sim\left(a_{i} S b_{j}\right) \wedge\left(b_{j} S a_{i}\right)$
$-a_{i} R b_{j} \Leftrightarrow \sim\left(a_{i} S b_{j}\right) \wedge \sim\left(b_{j} S a_{i}\right)$

$\mathrm{W}$ oparciu o relacje $\lambda$-preferencji zachodzące między wariantami a profilami wykonuje się przydział wariantów do klas. Można do tego celu wykorzystać dwie procedury, które dają jednak znacząco różne wyniki klasyfikacji. Procedury te noszą nazwę procedury optymistycznej i pesymistycznej. Procedura optymistyczna składa się z dwóch kroków:

1. Porównaj wariant $a_{i} z$ kolejnymi profilami $b_{j}$, rozpoczynając od najgorszego $\left(b_{0}\right)$.

2. Przydziel $a_{i}$ do klasy $C_{j}$, jeśli $b_{j}$ jest pierwszym napotkanym profilem, takim że $b_{j}>a_{i}$. Natomiast procedura pesymistyczna zbudowana jest następująco:

1. Porównaj wariant $a_{i} z$ kolejnymi profilami $b_{j}$, rozpoczynając od profilu najlepszego.

2. Jeśli $b_{j}$ jest pierwszym napotkanym profilem, dla którego $a_{i} S b_{j}$, to $a_{i}$ przydziel do klasy $C_{j+l}$ (La Gauffre i in., 2007). 
W publikacji zastosowano metodę Electre Tri, która znajduje zastosowanie np. w sytuacjach, kiedy zbadać należy bardzo dużą ilość wariantów decyzyjnych. Porównywanie ich parami mogłoby być kłopotliwe, wobec czego właściwe jest porównanie ich najpierw z profilami zaproponowanymi przez decydenta. Pozwala to odrzucić warianty najgorsze z punktu widzenia decydującego, a następnie rozpatrzyć inną metodą tylko te warianty, które znalazły się w najlepszych klasach jakościowych (Mousseau V. i.in., 2002).

\section{Drzewo kryterialne i kryteria oceny}

Konstrukcję modelu dla potrzeb oceny użyteczności problemu decyzyjnego oparto na rozwiązaniach metodycznych systemu DSS 3.0. Pakiet systemu DSS 3.0 umożliwił ocenę postawionego problemu decyzyjnego przy użyciu metod wspomagania decyzji Electre Tri. Aby odwzorować postawiony problem decyzyjny, w pierwszym kroku obliczeń należało stworzyć odpowiednie drzewo decyzyjne, tak aby zbudowany model był po części zautomatyzowany poprzez system DSS (Becker, Budziński, 2015). Jest to ważny problem dla każdej analizy przyczynowo-skutkowej czy optymalizacji wielokryterialnej. W opracowaniu drzewa kryterialnego (kryteria-podkryteria) posłużono się wytycznymi na podstawie kwestionariusza, który umożliwił dokładne badanie stanu pacjenta z chorobą zwyrodnieniową stawu biodrowego. W efekcie został utworzony zbiór kryteriów i podkryteriów, który tworzy „drzewo kryterialne” o strukturze adaptacyjnej.

Na poniższym rysunku 1 przedstawiono model drzewa decyzyjnego w ocenie badanego pacjenta z chorobą zwyrodnieniową stawu biodrowego, w którym uwzględniono specyfikację kryteriów i podkryteriów na podstawie kwestionariusza badanych pacjentów. W drzewie decyzyjnym występują parametry strojenia, tj. nadawania wag na potrzeby interpretacji i decyzji. Kryteria cząstkowe składają się z podkryteriów, które podporządkowane są lokalnemu strojeniu, czyli nadaniu odpowiednich wag (P). Preferencje dla kryteriów cząstkowych (F) są to tak zwane parametry preferencji odbiorców, stosowane w przypadkach kierowania rozwiązań różnych preferencji. Należy wspomnieć, że w rozpatrywanym przypadku założono preferencję (lekarz, fizjoterapeuta) metodą AHP oraz Electre Tri, którą przedstawiono w dalszej części pracy. 


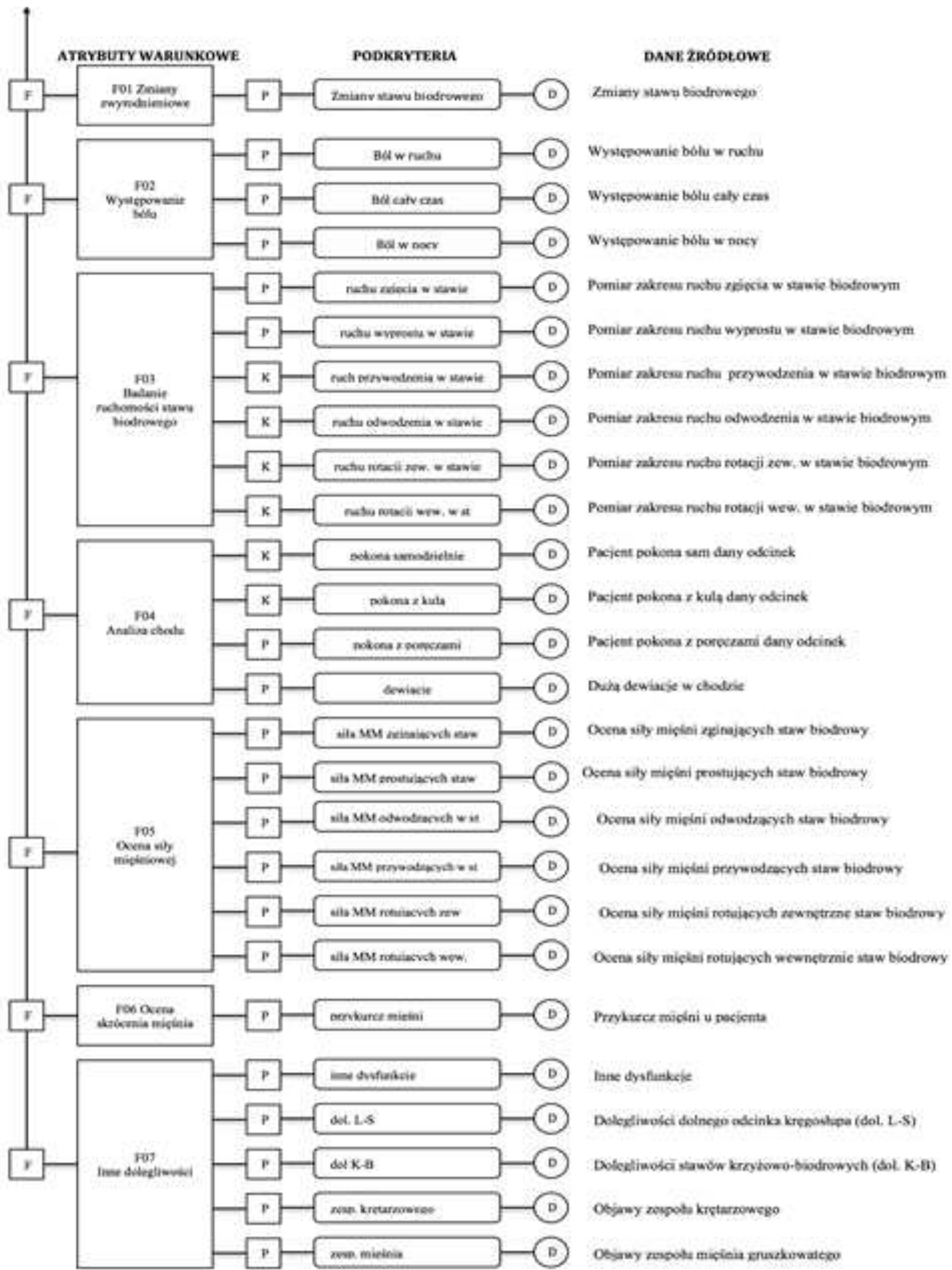

Rysunek 1. Model parametrów kryterialnych w ocenie badanego pacjenta z artrozą stawu biodrowego

Legenda: D - dane źródłowe od ekspertów (skala w pkt 0-5); P - parametry lokalnego strojenia podkryteriów (w \% suma $\mathrm{P}=100$ ); $\mathrm{F}$ - parametry preferencji odbiorcy, tj. kryteria funkcji celu WPL (w \% suma F) $=100$ 


\section{Weryfikacja badań}

Przedstawione badania oparto na wynikach z kwestionariuszy badań pacjentów z artrozą stawu biodrowego. Badaniom poddana została grupa 100 pacjentów oczekujących na zabieg wszczepienia endoprotezy stawu biodrowego. Badania przeprowadzono w Katedrze i Klinice Ortopedii, Traumatologii i Onkologii Narządu Ruchu Pomorskiego Uniwersytetu Medycznego w Szczecinie. Poprzez klasyfikacje praktyczną skategoryzowano wszystkie czynniki mające wpływ na bieżącą oraz przyszłą decyzję lekarza do zaklasyfikowania pacjenta z artrozą stawu biodrowego do operacji lub rehabilitacji.

Kwestionariusze sklasyfikowano za pomocą siedmiu cech (atrybuty warunkowe - rys. 1). W badaniach wykorzystano zmienne, które przyjmowały wartości całkowite z zakresu [0-5]. Dane charakteryzowały stan zmiennych jako: D01 - zmiany zwyrodnieniowe; D02 - występowanie bólu; D03 - badanie ruchomości stawu biodrowego; D04 - analiza chodu; D05 - ocena siły mięśniowej; D06 - ocena skrócenia mięśnia; D07 - inne dolegliwości.

Należy zaznaczyć, że przyjęcie samych kryteriów nie rozwiązało problemu wyboru decyzji. Konieczne było ustalenie wektora preferencji dla tych kryteriów. W związku z otrzymanymi wynikami nasuwają się pytania. Jakimi preferencjami kierują się lekarze, którzy klasyfikują pacjentów z artrozą stawu biodrowego do operacji? Na jakie cechy zwracają największą uwagę? Uzyskanie odpowiedzi oraz ustalenie wektora preferencji dla wybranych kryteriów wymaga zastosowania metody AHP (w ujęciu pojedynczym lub grupowym) identyfikującej w trybie dialogowym rozmyte wypowiedzi wybranej grupy ekspertów (lekarza/lekarzy lub fizjoterapeuty/fizjoterapeutów). Propozycję wykorzystania wspomnianej procedury przedstawiono na rysunku 2.

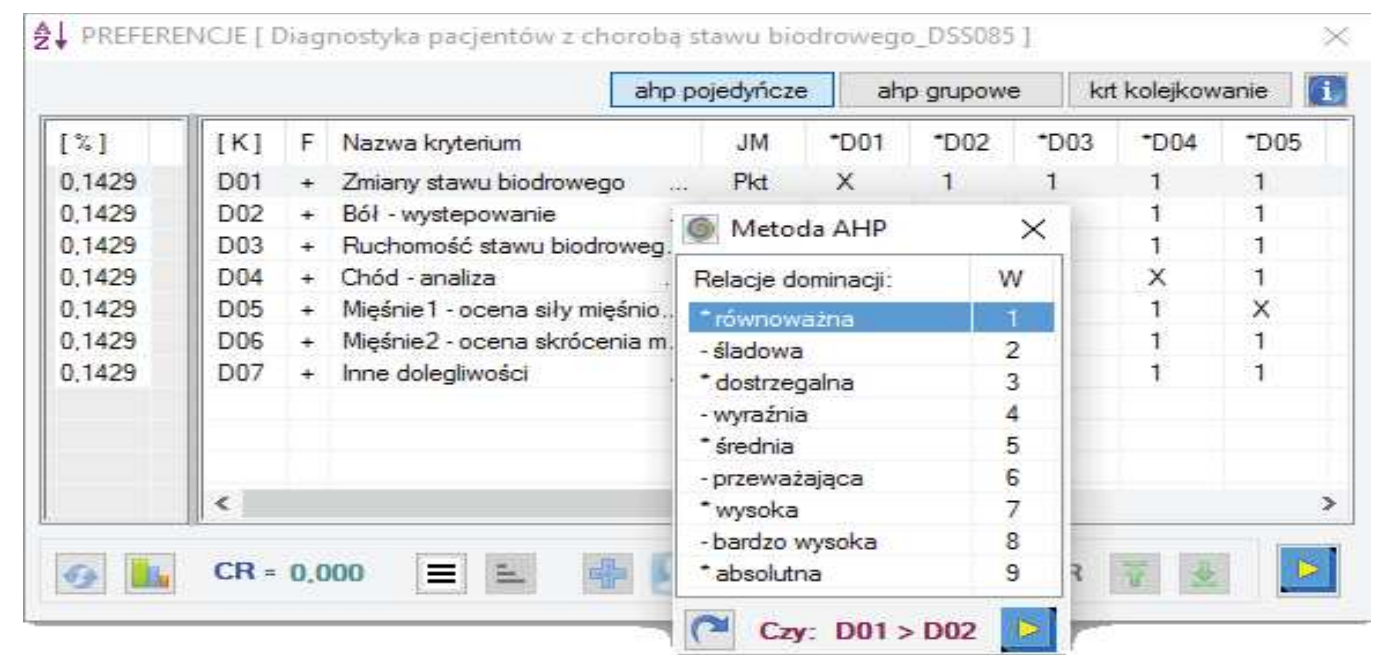

Rysunek 2. Ustalanie preferencji metodą AHP (porównania parami) w badanym problemie decyzyjnym Źródło: opracowanie własne na podstawie systemu DSS 3.0. 
Znajdujący się na wierzchołku hierarchicznej struktury decyzyjnej cel nadrzędny definiuje się jako stan docelowy (kwalifikacja do operacji) wynikający z odpowiedniego rozwiązania problemu decyzyjnego, w tym przypadku lekarza. Realizacja celu nadrzędnego przez każdy z wariantów wynika ze spełnienia celów pośrednich, które wyrażone są przez odpowiadające im kryteria i podkryteria.

Podstawą przeprowadzania obliczeń analitycznych jest utworzenie przechodniej bazy danych służącej wyłącznie do badań analitycznych i klasyfikacyjnych. Baza danych (rys. 3) do dalszego przetwarzania pochodzi z transpozycji wybranych parametrów (rys. 1) bilansów wspólnych i kryterialnych z modeli cząstkowych (rys. 2).

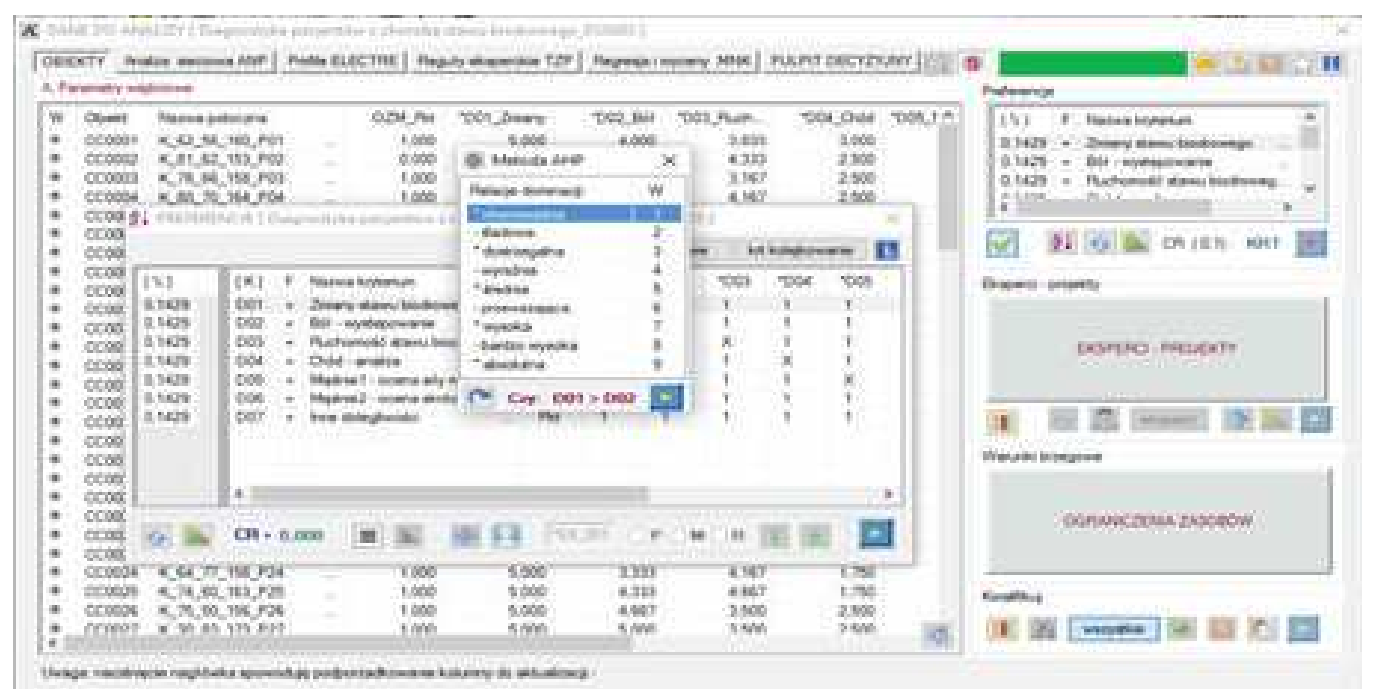

Rysunek 3. Zestawienie danych wejściowych do analizowania

Źródło: opracowanie własne na podstawie systemu DSS 3.0.

Po utworzeniu modelu, jak również drzewa decyzyjnego oraz wprowadzeniu do systemu DSS zestawu danych, w kolejnym etapie weryfikacji zastosowano metodę Electre Tri. Metoda ta została zaproponowana, aby wybrać najlepsze działania z danego zestawu kryteriów i podkryteriów oraz utworzyć ranking. Model grupowania Electre Tri nie narzuca przechodniości preferencji i dopuszcza sytuację nieporównywalności, jak już wspomniano we wcześniejszej części pracy. Wprowadzenie opracowanego rozwiązania informatycznego pozwoliło na odkrycie ,,pełniejszej" wiedzy o pacjentach, jak również w procesie decyzyjnym, czyli o wyborze lekarza. W efekcie otrzymujemy tzw. sprzężenie zwrotne, czyli gradację profili oraz reguły lingwistyczne, które przedstawiono na rysunku 4. 


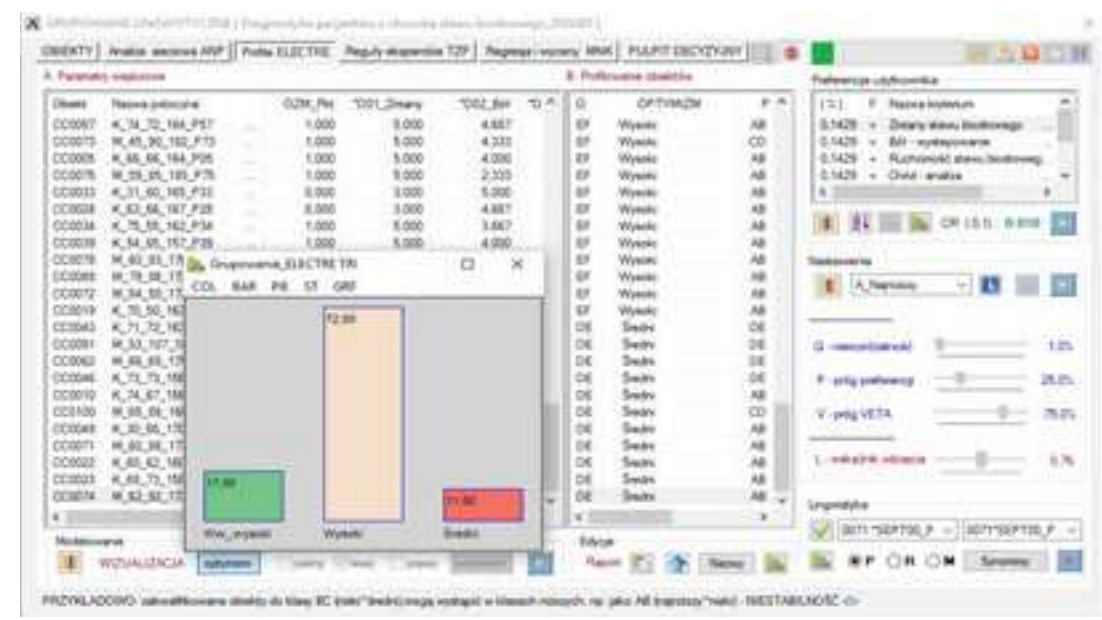

Rysunek 4. Ranking i grupowanie lingwistyczne obiektów w badanym problemie decyzyjnym Źródło: opracowanie własne na podstawie systemu DSS 3.0.

\begin{tabular}{|c|c|c|c|c|c|c|c|c|c|c|}
\hline notar & 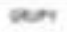 & 5 & ast & Int & wa & ses & $=4$ & sen & $\cos$ & se \\
\hline semori" & $v_{0}+\infty$ & 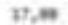 & $B, \mathrm{man}$ & nenes & $x=$ & $n, e m$ & H. 7 & t5, she & $65=$ & $87,0=0$ \\
\hline-5 anver: & 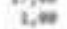 & 3,0 & $x=$ & $x=$ & $4,4 n$ & s.ma & 2.06 & 2.an & $x, \pi$ & N, $n$ \\
\hline Wrated" & $n, \omega$ & $n, m$ & 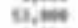 & $n s, \ldots=0$ & $2 \times 3, \omega 61$ & as, an & $m, \mathrm{men}$ & ac, na & $a_{1}, \mathrm{n}=$ & in, \\
\hline onsent: & 1,0 & $1, \mathrm{~m}$ & $\cos$ & 6,47 & 3, 21 & 3,264 & 2,04 & 3,734 & 1,60 & 7,63 \\
\hline "Sobes" & $n, m$ & 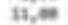 & 6.sen & 3,27 & $2, \mathrm{~min}$ & $2, \pi 3$ & $2, \pi$ & 3,62 & 0.06 & 2,72 \\
\hline , no olnkt: & 1. & \pm 0 &. .613 & e.2nt & 2. 81 & \&.32 & $0.3+6$ & $0,1 \mathrm{sis}$ & c.ans & 8.15? \\
\hline
\end{tabular}

Rysunek 5. Statystyka uzyskanych profili lingwistycznych w modelowaniu Electre Tri Źródło: opracowanie własne na podstawie systemu DSS 3.0.

Z przedstawionego zestawienia (rys. 4 i rys. 5) wynika, że zbiorowość charakteryzowała się wartościami wysokimi (72\%). Należy zwrócić uwagę przede wszystkim na profil Ww_wysoki, który klasyfikuje pacjenta do natychmiastowego zabiegu operacyjnego wymiany stawu biodrowego. Jak wiadomo decyzja o operacji powinna nastąpić po rzetelnej eliminacji innych możliwych dysfunkcji generujących lub wzmagających dolegliwości pacjenta. W sytuacji gdy profil jest wysoki (72\%) oraz średni (11\%), można zastosować farmakoterapię lub dobrze zaplanowaną fizjoterapię, która może oddalić konieczność zabiegu operacyjnego lub zmniejszyć przykre dolegliwości w trakcie oczekiwania na zabieg endoprotezoplastyki.

\section{Wyniki końcowe}

W związku z przeprowadzonymi badaniami celem pracy było wyłonienie pacjenta, który w założonej a priori pięciostopniowej skali profilowania proporcjonalnego (Ww_wysoki, wy- 
soki, średni, niski, najniższy) najlepiej spełnia postulat zakwalifikowania do operacji. Wyniki $\mathrm{w}$ formie rankingu hierarchicznego przeprowadzonych analiz przedstawiono w tabeli 1.

Tahbela 1. Ranking klasyfikacji badanych pacjentów z chorobą zwyrodnieniową stawu biodrowego

\begin{tabular}{|c|c|c|c|c|c|c|c|c|c|c|}
\hline Lp & Nazwa potoczna & $\mathrm{C} 01$ & D01 & D02 & D03 & D04 & D05 & D06 & D07 & OPTYMIZM \\
\hline 1 & K_64_58_156_P12 & 1 & 5 & 5 & 3,333 & 2,5 & 3,667 & 5 & 4 & Ww_wysoki \\
\hline 2 & K_83_67_167_P13 & 1 & 5 & 4,333 & 3,833 & 1,5 & 3,5 & 5 & 4 & Ww_wysoki \\
\hline 3 & K_78_82_163_P21 & 1 & 5 & 4,333 & 3,833 & 1,75 & 3,167 & 5 & 4 & Ww_wysoki \\
\hline$\ldots$ & $\ldots$ & $\ldots$ & $\ldots$ & $\ldots$ & $\ldots$ & $\ldots$ & $\ldots$ & $\cdots$ & $\ldots$ & $\ldots$ \\
\hline 7 & K_67_83_164_P51 & 1 & 5 & 3,333 & 4,333 & 1,75 & 3 & 5 & 3 & Ww_wysoki \\
\hline 8 & K_80_68_162_P20 & 1 & 5 & 5 & 4,167 & 1,5 & 2,5 & 5 & 3 & Ww_wysoki \\
\hline 9 & M_77_65_164_P77 & 1 & 5 & 5 & 4,667 & 2 & 2,833 & 5 & 2 & Ww_wysoki \\
\hline 10 & K_75_50_156_P26 & 1 & 5 & 4,667 & 3,5 & 2,5 & 3 & 5 & 2 & Ww_wysoki \\
\hline$\ldots$ & $\ldots$ & $\ldots$ & $\ldots$ & $\ldots$ & $\ldots$ & $\ldots$ & $\ldots$ & $\ldots$ & $\ldots$ & $\ldots$ \\
\hline 18 & M_58_72_176_P87 & 1 & 5 & 4 & 3,5 & 3,25 & 4 & 5 & 4 & Wysoki \\
\hline 19 & K_67_64_160_P35 & 0 & 3 & 4,667 & 3,833 & 2,5 & 4 & 3 & 5 & Wysoki \\
\hline 20 & M_49_80_181_P93 & 1 & 5 & 4,667 & 3 & 2,5 & 4,167 & 3 & 4 & Wysoki \\
\hline 21 & K_80_65_165_P09 & 0 & 3 & 4 & 3 & 2 & 3,833 & 3 & 5 & Wysoki \\
\hline 22 & K_78_65_154_P32 & 1 & 5 & 4,333 & 4,167 & 1,75 & 3,833 & 3 & 4 & Wysoki \\
\hline 23 & K_78_66_158_P03 & 1 & 5 & 4,667 & 3,167 & 2,5 & 3,833 & 3 & 4 & Wysoki \\
\hline 24 & M_77_93_180_P95 & 1 & 5 & 4,667 & 3,5 & 2 & 3,667 & 3 & 4 & Wysoki \\
\hline$\ldots$ & $\ldots$ & $\ldots$ & $\ldots$ & $\ldots$ & $\ldots$ & $\ldots$ & $\ldots$ & $\ldots$ & $\ldots$ & $\ldots$ \\
\hline 93 & K_73_73_156_P46 & 1 & 5 & 3 & 3,667 & 2 & 3,333 & 3 & 2 & Średni \\
\hline 94 & K_74_67_156_P10 & 0 & 3 & 3 & 3,333 & 3,75 & 5 & 0 & 2 & Średni \\
\hline 95 & M_65_88_166_P100 & 1 & 5 & 2,667 & 2,167 & 2 & 3,833 & 1 & 2 & Średni \\
\hline$\ldots$ & $\ldots$ & $\cdots$ & $\cdots$ & $\ldots$ & $\ldots$ & $\ldots$ & $\ldots$ & $\cdots$ & $\cdots$ & $\ldots$ \\
\hline 99 & K_68_73_158_P23 & 0 & 1 & 3,333 & 1 & 3,75 & 4,667 & 0 & 2 & Średni \\
\hline 100 & M_62_92_172_P74 & 0 & 3 & 3,667 & 2,5 & 3,25 & 4,333 & 0 & 0 & Średni \\
\hline
\end{tabular}

Źródło: opracowanie własne.

Wyniki pokazane w tabeli 1 przedstawiają grupę badanych pacjentów z chorobą zwyrodnieniową stawu biodrowego. Należy zaznaczyć, że ostatecznym etapem leczenia choroby zwyrodnieniowej stawu biodrowego jest endoprotezoplastyka. W przedstawionym przypadku to ok. 17\% pacjentów, którzy wymagają natychmiastowego zabiegu operacyjnego. Operacja niesie za sobą poprawę stanu funkcjonalnego, ale również ryzyko powikłań i innych zagrożeń. Przedstawiony ranking może pomóc lekarzom i fizjoterapeutom w podjęciu decyzji o sposobie leczenia. Choroba zwyrodnieniowa stawu biodrowego jest chorobą przewlekłą. Nie da się cofnąć zaistniałych zmian, ale odpowiednio dobrana rehabilitacja jest w stanie spowolnić postęp choroby, poprawić sprawność i komfort życia chorego oraz oddalić konieczność operacji zwłaszcza u pacjentów, którzy muszą czekać latami na endoprotezoplastykę. 


\section{Podsumowanie}

$\mathrm{W}$ artykule zweryfikowano ocenę stanu funkcjonalnego pacjenta z chorobą zwyrodnieniową stawu biodrowego do operacji z zastosowaniem relacji przewyższenia (Electre Tri). Badania te łączą niezbędną ilość informacji dotyczących subiektywnych odczuć pacjenta z badaniem funkcjonalnym, które za pomocą pomiarów i testów, jak również metody decyzyjnej wspomogą lekarza w podjęciu decyzji. Należy wspomnieć, że warunkiem jest posiadanie wiedzy o preferencjach wskazanej grupy badanych i dostosowanie opisu metod do odwzorowywanej rzeczywistości, w tym przypadku lekarza. Metoda Electre Tri pomija w klasyfikacjach atrybut decyzyjny, tj. nie wprowadza się zmiennej zależnej, co pozwala na odkrywanie „niezdominowanej” wiedzy o rozpatrywanym procesie decyzyjnym. W wyniku przeprowadzonych badań otrzymaliśmy ranking klasyfikacji badanych pacjentów do operacji. Artykuł ukazuje w obiektywny sposób faktyczny stan fizyczny badanego pacjenta. Badanie pacjenta według zaproponowanego narzędzia umożliwia klasyfikację oraz weryfikację pacjentów do leczenia. Warto również uwzględnić koszty leczenia ponoszone przez budżety państw. Koszty te są ogromne i stale rosną, a związane są z rozpoznaniem, leczeniem, rehabilitacją, absencją zawodową i świadczeniami rentowymi pacjentów z chorobą zwyrodnieniową stawu biodrowego. Niedoskonałość systemów opieki zdrowotnej, błędna diagnoza oraz standardowe programy rehabilitacyjne wydłużają leczenie, tym samym pogłębiają stan degradacji stawu, zwiększając niesprawność i dolegliwości bólowe. Należy poszukiwać zatem takich narzędzi, które by usprawniły nie tylko podjęcie decyzji przez lekarza, ale również wspomogły leczenie pacjenta poprzez odpowiednią fizjoterapię czy farmakoterapię.

\section{Litepatupg}

Arokoski, M., Haara, M., Helminen, H., Arokoski, J. (2004). Physical function in men with and without hip osteoarthritis. Archives of Physical Medicine and Rehabilitation, 85(4), 574-581.

Arokoski, H. I in. (2002). Hip muscle strength and cross-sectional area in men with and without hip osteoarthritis. The Journal of Rheumatology, 29, 2185-2195.

Becker, J., Budziński, R. (2015). Transformation of Knowlege Suorces in Decision Support System. Journal of Automation, Mobile Robotics \& Intelligent Systems, 9/2, 28-36.

Lexer, M., Vakic, H. (2007). Multiple Criteria Decision Making in Natural Resource Management, Lecture Notes. Wien: Universität für Bodenkultur.

Mamaghani, F. (2002). Evaluation and selection of an antivirus and content filtering software. New York: St. John Fisher College.

Mousseau, V., Słowiński, R., Zielniewicz, P. (2002). Electre Tri 2.0a Methodological guide and user's manual, s. 9-21. Paryż: Universite Paris Dauphine.

Mousseau, V., Słowiński, R. (1998). Inferring an Electre Tri Model from Assignment Examples, s. 1-18. Amsterdam: Kluwer Academic Publishers.

Srokowski, G., Bułatowicz, I., Kaźmierczak, U., Tyma, R., Radzimińska, A., Strojek, K., Srokowska, A. (2010). Ocena jakościowa chodu oraz badanie funkcji biodra pacjentów zakwalifikowanych do zabiegu endoprotezoplastyki stawu biodrowego. Nowiny Lekarskie, 79(3), 183-190.

Suetta, C. I in. (2007). Muscle size, neuromuscular activation, and rapid force characteristics in elderly men and women: effects of unilateral long-term disuse due to hip-osteoarthritis. Jurnal of Applied Physiology, 102(3), 942-948 


\title{
APPLICATION OF METHOD FOR MULTI-CRITERIA DIAGNOSTIC ANALYSIS OF PATIENT WITH OSTEOARTHRITIS OF THE HIP
}

\author{
KEYWORDS $\mid$ MCDM, Electre Tri, AHP, Hip osteoarthritis \\ ABSTRACT Advanced degenerative changes causing disturbances in biomechanics, disability and social iso- \\ lation. A multitude of conditions of varying severity of the patient causes problem with determin- \\ ing the optimal timing of treatment. The classification of patients for surgery is complex. Pub- \\ lished studies show a variety of parameters, variants and classification of evaluable patients with \\ osteoarthritis of the hip. It notes the lack of proposals for assessing the performance in the field of \\ biomechanics in one system, and with the classification of a sick patient. The paper presents the \\ problem of the methodology for specific decision problems. \\ The aim of the article was to develop (and verify) test procedure for the evaluation of osteoar- \\ thritis of the hip. Verified appropriate method of multi-criteria Electre Tri, which allowed to \\ established patient qualifications for surgery or hip replacement program of physiotherapy or \\ pharmacotherapy.
}

